Практическая значимость. Приведены рекомендации по усилению либеральной составляющей во внешнеэкономических отношениях аграрного обращения. Табл.: З. Библиогр.: 12.

Ключевые слова: сельскохозяйственная продукция; цена; динамика; Украина; Польша; Израиль; пандемия; COVID-19.

Губени Юрий Эдвардович - доктор экономических наук, профессор, заведующий кафедрой предпринимательства, торговли и биржевой деятельности, Львовский национальный аграрный университет (80381, ЛьвовДубляны, ул. Владимира Великого, 1)

E-mail: hubeni@ukr.net

ORCID iD https:/ / orcid.org/ 0000-0002-1842-8975

Биттер Александр Аронович - доктор экономических наук, профессор, независимый исследователь (80381, Львов-Дубляны, ул. Зеленая, 3, кв. 77)

E-mail: abitter@ukr.net

ORCID iD https:/ / orcid.org/ 0000-0001-5905-6509

Стаття надійшла до редакції 06.07.2021

Фахове рецензування: 02.08.2021

Бібліографічний опис для цитування:

Губені Ю. Е., Біттер О. А. Цінові тенденції та цінові співвідношення в умовах пандемії COVID-19: кейс-аналіз окремих країн. Економіка АПК. 2021. № 8. С. 103 - 111. https:// doi. org/ 10.32317/ 2221-1055.202108103

Hubeni, Yu.E. \& Bitter, O.A. (2021). Tsinovi tendentsii ta tsinovi spivvidnoshennia v umovakh pandemii COVID-19: keis-analiz okremykh krain [Price trends and price ratio in the COVID-19 pandemic: case analysis of some countries]. Ekonomika APK, 8, pp. 103 - 111 [In Ukrainian]. https:/ / doi. org/ 10.32317/ 2221-1055.202108103

UDC 338.439

J EL Classification: 013; P36; Q17

DOI: https:/ / doi.org/ 10.32317/ 2221-1055. 202108111

B. V. DUKHNYTSKYI, doctor of economic sciences

\title{
Food supplying in Ukraine and the world under COVID-19 pandemic
}

The purpose of the article is to study an impact of COVID-19 pandemic on the functioning of global agricultural market, situation with food supplying in Ukraine and other countries, as well as to assess development of related processes in the near future.

Research methods. Methods used: theoretical generalization - for describing the overall situation in global, regional and national agri-food markets due to the effects of coronavirus pandemic from 2020 to the present, analysis and synthesis - for studying food security in separate countries and globally for now and in the near future, taking into account current situation, finding aggregate values of world agricultural trade for the analyzed period, comparative evaluation - for comparing quantitative, cost and other relative indicators that characterize food supplying in 2019 and 2020, finding confirmatory or negative relevant trends during the incomplete year 2021, graphical and tabular - for better visualization of quantitative indicators used in the article.

Research results. The dissemination of anti-pandemic measures in the world and in Ukraine is considered, the growth of absolute and relative food expenditures in different regions of the world is shown, quantitative data on undernourished people in some parts of the world are given, the situation with agri-food imports to Ukraine and its influence in 2020-2021 on the domestic market is determined, price indices for food in the world according to FAO and Ukraine according to state statistics, including quantitative consumption, are described, showed summary estimations for production major groups of crop and livestock products until 2030 inclusive.

Scientific novelty. The difference in indicators of agri-food trade, food expenditures, number of people suffering from hunger, as well as price indices for basic food products in the world in general and in Ukraine in particular between "pre-pandemic" 2019 and 2020-2021, which are characterized by significant spread of the pandemic

Practical significance. The provisions of the article are aimed at informing Ukrainian agricultural enterprises with foreign economic profile, consumers of products and government agencies about changes in domestic and foreign agricultural markets in order to develop a common strategy and tactics of possible actions and systematical measures to prevent negative consequences due to significant increase in uncertainties over the past period. Tabl.: 2. Figs.: 2. Refs. : 17

Keywords: COVID-19 pandemic; trade restrictions; food expenditures; number of undernourished people; price index; food consumption; production forecast.

(c) B. V. Dukhnytskyi, 2021 
Dukhnytskyi Bohdan Volodymyrovych - doctor of economic sciences, senior research fellow of the department of agrarian production economics and international integration, National Sciences Centre "Institute of Agrarian Economics"

(10, Heroiv Oborony St., Kyiv, 03127)

E-mail: duhnitsky@faust.kiev.ua

ORCID iD https:/ / orcid. org/ 0000-0002-5521-5602

Scientific problem. Providing food to its own population is traditionally one of the most important functions for every state. Many efforts at all levels and material resources of financial and production character are subject for its achievement. Usually this issue is successfully resolved, unless there are any uncertanties. However, the year 2020 posed new challenges to society due to spread of the coronavirus pandemic. Unprecedented restrictions in all spheres of economy and everyday life, including international activities, have significantly reformatted the usual priorities of world food trade. Along with forced measures to prevent the pandemic on a global scale, many governments have resorted to restricting or banning an export of essential medicines and basic foodstuffs, primarily grain and grain products. Under such conditions, the general situation in the world in terms of the number of undernourished and stability of supplies agricultural raw products and food to foreign markets has deteriorated significantly. This was particularly acute in those countries that are heavily dependent on imports of certain or many major groups of agri-food products. Although the most significant restrictions in trade between countries were observed in the first half of 2020, causing a serious decline in export-import transactions with agricultural goods together with curtailment of foreign economic activity in general, in the current circumstances the possibility of new deterrents cannot be completely excluded. The available statistics will help to demonstrate more clearly an actual consequences of the fixed processes and to consider possible forecast for development of the world agricultural market.

Analysis of recent researches and publications. Issues of food security on a national and global scale, including the impact of production and trade in agricultural products are covered in the publications of Ukrainian agrarian scientists, in particular Yu. O. Lupenko $[7,8]$, M.I. Pugachov [8, 9], V.I. Vlasov [3], O.M. Shpychak [7], O.G. Shpykuliak [9], O.V. Khodakivska [9] and other foreign authors [17]. Thematic data on this issue are contained in regular materials of domestic [1$6]$ and international profile structures [10-16].
The purpose of the article is to study an impact of COVID-19 pandemic on the functioning of global agricultural market, situation with food supplying in Ukraine and other countries, as well as to assess development of related processes in the near future.

Research methodology. Restrictive measures in the world economy and trade since the beginning of coronavirus pandemic are traced according to periodical publications of specialized resources. First results of the functioning these spheres under structurally new conditions can be seen by comparing relevant indicators for 2020 and 2019, as well as available operational data for 2021. In the context of the article, absolute and relative costs of food, consumer price indices and forecasts of agri-food production in Ukraine and in the world are considered. Current statistics on the number of starving people in the world, its regions and separate countries are taken from report «The State of Food Security and Nutrition in the World - 2021». Greater emphasis is placed on atypical changes in the domestic food market, increasing agricultural imports by our country and reducing the volume of consumption key product groups according to official statistics.

Research results. The coronavirus pandemic began in late 2019 as an outbreak of unknown disease in China's Wuhan province, then spread rapidly to other countries, causing socalled "lockdowns" and de facto collapse in most areas of the economy and public life.

From the very beginning of 2020 the process of moving any goods has become more complicated, as quarantine restrictions have been introduced around the world, including Ukraine and the main trading partner countries for us. China's ports, which is the main market for domestic agri-food products, were practically closed in J anuary-February, and in the spring months the disease began to rage in European countries and the United States. Moreover, due to their own congestion, Chinese ports, even after a critical period of spread the disease in the country, for some time did not work normally. The European Union, Ukraine's second-largest regional market for agricultural products, was currently 
introducing additional border controls. These delays have led to the most difficult situation in international trade in short-lived products, including fruit and vegetables. Therefore, there was often a situation with the rejection of the planned deliveries of these product groups due to the inability to guarantee their proper quality and timeliness of delivery to the final buyer. Unfortunately, this problem has not escaped from domestic exporters of fresh fruits and vegetables [9].

Other negative consequences of the pandemic at the beginning of its spread were the dissemination of panic consumer sentiment about the virus itself, which directly affected international trade. For example, when the situation in Italy deteriorated rapidly in the spring, many countries refused to purchase traditional Italian products because people feared that they could be contaminated through the surfaces of packaging or ready-toeat products. Therefore, people did not buy the goods that were imported earlier. As a result, prices could not remain at the same level and were forced to fall for some time. The decline in world trade in agricultural products was also caused by declining food imports by countries with devaluation of national currencies. Another negative result of the cessation and restriction of transportation goods at that time was a serious increase in the cost of international delivery containers by sea.

In the first half of 2020, a number of countries introduced temporary bans on the export of most food-critical products, mainly cereals. In particular, export of buckwheat was banned in Ukraine until July 1 last year, and the situation with wheat was under constant government monitoring. Authorities in $\mathrm{Vi}$ etnam have imposed quotas on rice exports, while the Philippines, Myanmar and Cambodia have not allowed it to be exported at all. There were also bans on the sale to foreign markets of wheat, corn, barley, rye, buckwheat, sorghum, various legumes, peas, cereals and flour. Such measures were taken by Tajikistan, Sudan, Romania, Northern Macedonia, Honduras, El Salvador, Egypt, Belarus and other countries. It should be noted that the vast majority of these restrictions did not have a clear timeline for their completion, as the further development of the coronavirus pandemic remained unpredictable [16].
For comparative analysis of various indicators related to food security, it is advisable to compare the data of 2019, when global pandemic did not spread, with the data of 2020, which show changes in the conditions of coronavirus. Of course, it is not possible to draw unambiguous conclusions from them, as not in all countries the situation developed according to a similar scenario, but this is enough to give a general assessment the impact of COVID-19.

According to the US Department of Agriculture (USDA), which monitors food expenditures around the world, overall average percentage for the entire sample (104 countries) increased from $22,5 \%$ in 2019 to $23,5 \%$ in 2020 [10]. At the same time, in monetary terms, the amount spent on average by one individual on food and soft drinks for home consumption has also increased - from 1266 USD in 2019 to 1303 USD in 2020. It will be more informative to compare groups of countries that have different shares of food costs - from minimum to maximum. Thus, in countries with food costs of up to $10 \%$ (USA, UK, etc., only 4 countries), the average value of this indicator increased from 7,5\% in 2019 to $8,5 \%$ in 2020, while the amount that the average population of these countries spent on food for the analyzed period increased from 1966 USD/ person to 2005 USD/ person. This pattern is maintained for all other groups of countries, differentiated by expenditures (from more than $10 \%$ to $20 \%$ from more than $20 \%$ to $30 \%$ from more than $30 \%$ to $40 \%$ from more than $40 \%$. In the group with food expenditures in the range of more than $20 \%$ to $30 \%$ (Latvia, Turkey, China, Mexico, etc., totally 30 countries), the corresponding figures increased from $23,9 \%$ to $25,3 \%$ and from 1118 USD/person up to 1178 USD/person. And for the group where food expenditures exceed $40 \%$ in the structure of total consumer spending (Pakistan, Ukraine, Ghana, Cambodia, Kenya, etc., a total of 17 countries) from 2019 to 2020, the following increase was recorded from $46,1 \%$ to $47,3 \%$ and from USD $747 /$ person to USD 771/ person (Table 1). As for Ukraine, the global trend has also been confirmed: share of food expenditures by one of our citizens increased from $39,7 \%$ in 2019 to $41,2 \%$ in 2020 , and the amount of money spent on the purchase of food and soft drinks for the same time - from 874 USD/person to 964 dollars USD/ person [10]. 
Table 1. Classification of countries according to the average expenditures on food per 1 person

\begin{tabular}{|c|c|c|c|c|}
\hline \multirow[t]{2}{*}{ Countries } & \multicolumn{2}{|c|}{$\begin{array}{c}\text { Percent of consumer } \\
\text { expenditures spent on food, \% }\end{array}$} & \multicolumn{2}{|c|}{$\begin{array}{c}\text { Expenditures on food, } \\
\text { USD }\end{array}$} \\
\hline & 2019 & 2020 & 2019 & 2020 \\
\hline With expenditures in the range $\leq 10,0 \%$ & 7,5 & 8,5 & 1966 & 2005 \\
\hline incl. USA & 6,2 & 7,1 & 2357 & 2596 \\
\hline United Kingdom & 7,9 & 9,4 & 1832 & 1951 \\
\hline $\begin{array}{l}\text { With expenditures in the range } \\
>10,0 \% \leq 20,0 \%\end{array}$ & 14,0 & 15,1 & 2053 & 2096 \\
\hline incl. Ireland & 8,6 & 10,3 & 1779 & 1919 \\
\hline Japan & 15,3 & 15,7 & 3116 & 3038 \\
\hline Poland & 16,4 & 19,1 & 1301 & 1516 \\
\hline $\begin{array}{l}\text { With expenditures in the range } \\
>20,0 \% \leq 30,0 \%\end{array}$ & 23,9 & 25,3 & 1118 & 1178 \\
\hline incl. China & 19,4 & 21,8 & 743 & 883 \\
\hline Lithuania & 20,2 & 24,5 & 2251 & 2692 \\
\hline India & 27,2 & 27,9 & 338 & 326 \\
\hline $\begin{array}{l}\text { With expenditures in the range } \\
>30,0 \% \leq 40,0 \%\end{array}$ & 33,3 & 34,2 & 811 & 827 \\
\hline incl. Indonesia & 32,3 & 32,6 & 701 & 693 \\
\hline North Macedonia & 33,0 & 34,4 & 1213 & 1186 \\
\hline Egypt & 36,2 & 39,8 & 1026 & 1240 \\
\hline With expenditures in the range $>40,0 \%$ & 46,1 & 47,3 & 747 & 771 \\
\hline incl. Ghana & 38,4 & 41,6 & 505 & 566 \\
\hline Kazakhstan & 47,1 & 48,7 & 2102 & 2217 \\
\hline Myanmar & 55,9 & 56,3 & 490 & 513 \\
\hline
\end{tabular}

Source: Formed by author based on [10].

Another important indicator that characterizes global food security is the number of people suffering from hunger, and in the context of impact the pandemic, changes that have taken place in this indicator since 2020. If we compare with 2019 in general, negative trend continued, the number of hungry people increased again. Note that last year's data by FAO experts are not specified, and final figure in the world is given in the range, but it has grown faster than in previous years. If in 2019 number of starving people on our planet was 650 million, in the "pandemic" 2020 its estimates range from a minimum of 720 million to a maximum of 811 million. At the same time, the average is 768 million starving. Among the regions with highest number of people suffering from hunger, growth was also recorded: in Asia - from 361 million in 2019 to 418 million in 2020, in Africa - from 235 million to 282 million, in Latin America and the Caribbean - from 46 million to 60 million respectively [15].

For our country, last year was also a challenge in terms of food security. Coronavirus restrictions, which were introduced in March, accompanied not only by a forced pause in social and economic life, but also directly affected on the income and expenditure of

citizens. Period of stress that economy was experiencing at this time was truly unique, as it had no complete analogues in terms of the degree of rigidity and duration of restrictive measures. Situation was exacerbated by the fact that majority of the population had little or no savings, which would have made it easier to cope with sudden crisis of losing a source of stable income. Such factors have created many preconditions for saving consumer costs, including their main part related to food. It is confident to say that at that time the socio-economic situation in Ukraine was characterized by great unpredictability, along with many signs of crisis. Such experience in the past, unequivocally, among other things, has led to a decrease in imports of agri-food products to Ukraine. Such cases occurred in 2009, when after the accession to the WTO and growing dynamics of foreign purchases, impact of the global economic crisis, as well as in 2014-2015 due to the annexation of Crimea and active hostilities in the Donbass. The most logical was another decline in agricultural imports, but in the end it reached 6498 million dollars, continuing the growing trend and exceeding 2019 by 13\% That is, this result became atypical and 
unique for Ukraine in general. In addition, despite on all the obstacles to international trade, our country, although insignificant, but was able to increase the value of agricultural exports, setting another record in 2020 22179 million dollars [4, 5].

It is worth to say that last year there was an increase in the value of imports in all major product groups, including fruits and berries, fish and seafood, alcoholic and nonalcoholic drinks, tobacco products and various food products. Quantitative increases also applied for these items, with the exception of tobacco products. At the same time, there is a tendency to exceed imports over exports for many products that are traditional for our agricultural production, including live birds in poultry, pork, lard and fat, various vegetables (potatoes, tomatoes, cucumbers, cabbage, onions). Separately, we note the purchase of cheese abroad, which has actually doubled from 24 thousand tons in 2019 to 47 thousand tons in 2020 [4, 5].

In 2021 value of imports continued to increase in general, including livestock, crop products, oils and fats, ready-to-eat foods, and in most of previously named major product groups, except for tobacco products. In the first half of this year, agri-food imports to Ukraine as a whole amounted to 3633 million dollars, $20 \%$ higher than in the same period of 2020. An additional negative point against this background was a significant increase in sugar imports - from less than 1 thousand tons in J anuary-J une 2020 to over 102 thousand tons in the same period of 2021. Over time, this figure has grown even more. Although the volume of foreign purchases of this sweet product in our country has increased sharply in some years due to unfavorable domestic market conditions, this year it has become another typically traditional product for the domestic agricultural sector, which has a negative foreign trade balance $[4,5]$. Thus, during 2020-2021, the dependence of the domestic Ukrainian food market from on imported food supplies has increased.

The increase in the value of international trade was also observed worldwide. According to the International Trade Center (ITC), exports of product groups 1-24 increased from 1591 billion dollars in 2019 to 1619 billion dollars in 2020 [13].

Another parameter that will allow us to assess food supplying in 2020 is the expenditures on food for households, according to domestic statistics. Additionally, it can be used to estimate the shares on the domestic food market for Ukrainian and foreign products. In general, last year the total cost of food remained unchanged compared to 2019 and amounted to $4682 \mathrm{UAH} /$ month for one household. The main difference in their structure is the reduction of the money amount spent on meals outside the home - from $180 \mathrm{UAH} /$ month to $106 \mathrm{UAH} /$ month. At the same time, an increase in the cost of food consumed at home was recorded for the same amount. The annual value of the domestic food market capacity is calculated by multiplying the monthly cost of food, taking into account the number of households in Ukraine, which is 14784300. Thus, according to these data, capacity of the domestic food market in Ukraine in 2020 amounted to approximately UAH 831 billion, having decreased about UAH 5 billion in comparison with 2019 [2, 7]. This was mainly due to a reduction in the total number of households. As a result, for our country, the reduction in capacity of the food market was another unusual result of last year, because before that it was constantly growing.

Similarly, using average annual official exchange rate of the national currency $(26,96$ UAH/ USD in 2020), we determine the value of imports an agri-food products in UAH. According to the described method, it was equal to 175 billion UAH. Last year, imported products accounted for $21 \%$ on the Ukrainian food market, while domestic products accounted for $79 \%$ For the first time in a long time, share of domestic food became less than $80 \%$ because even according to estimates for 2017 and 2019, after a severely devalued hryvnia, the ratio of Ukrainian and imported products was unchanged $-82 \%$ and $18 \%$ respectively. It is also noteworthy that the share of retail sales different food products produced in Ukraine continued to decline - from $80 \%$ in 2019 to $79 \%$ in $2020[5,7]$.

According to the monitoring of the Food Price Index by the Food and Agriculture Organization of the United Nations (FAO), in September 2021 its value was almost 33\% higher than at the same time last year. This means that, in general, the average values of price indices for the five product groups (cereals, vegetable oils, dairy products, meat, sugar), which are its components, have grown significantly during the pandemic. Especially 
noticeable, given the dynamics, the rise in price became in 2021. In particular, the Grain Price Index in September this year increased by $27 \%$ compared to September 2020, the Vegetable Oil Price Index increased by $60 \%$ the Dairy Price Index - by $15 \%$ the Meat Price Index - by $26 \%$ Sugar price index - by 54\% [11]. Thus the growth of prices is recorded for absolutely all food groups, and as of now we can say that there are no prerequisites for their stabilization, because new marketing year began for many products in J uly-September, so expected trends in harvest and production have become known to all stakeholders.

Analysis of the price index for food and nonalcoholic beverages in Ukraine shows that in 2020 its growth was one of the lowest in the last period (102,7\% compared to the previous year), while in 2019 this figure was $108 \%$ However, this year inflation has accelerated significantly, and since J anuary the food price index has been rising steadily. In J anuary-J une 2021 it amounted to $108,9 \%$ compared to the same period last year. In the second half of the year this trend continues. There is an increase in the price of all product groups except for vegetables with an index of $89,7 \%$ in the first six months of this year. And the most noticeable was the increase in prices for sugar - $164,0 \%$ eggs $-160,8 \%$ sunflower oil - 154,6\%[5].

In this context, there is continuing decline in the energy value of food consumed - from $2951 \mathrm{kcal} / \mathrm{day}$ in 2019 to $2862 \mathrm{kcal} / \mathrm{day}$ in 2020 per person - is quite expected, although it still exceeds the maximum allowable value of this indicator at $2500 \mathrm{kcal} /$ day $[5,6]$. The negative also extended to quantitative indicators of consumption of key food groups. Thus, in 2020 in Ukraine average consumption of bread and bakery products, potatoes, vegetables and melons, fruits, berries and grapes, milk, eggs, fish, sugar decreased, this indicator remained unchanged for oil, and increased only for meat and meat products (Figure 1).

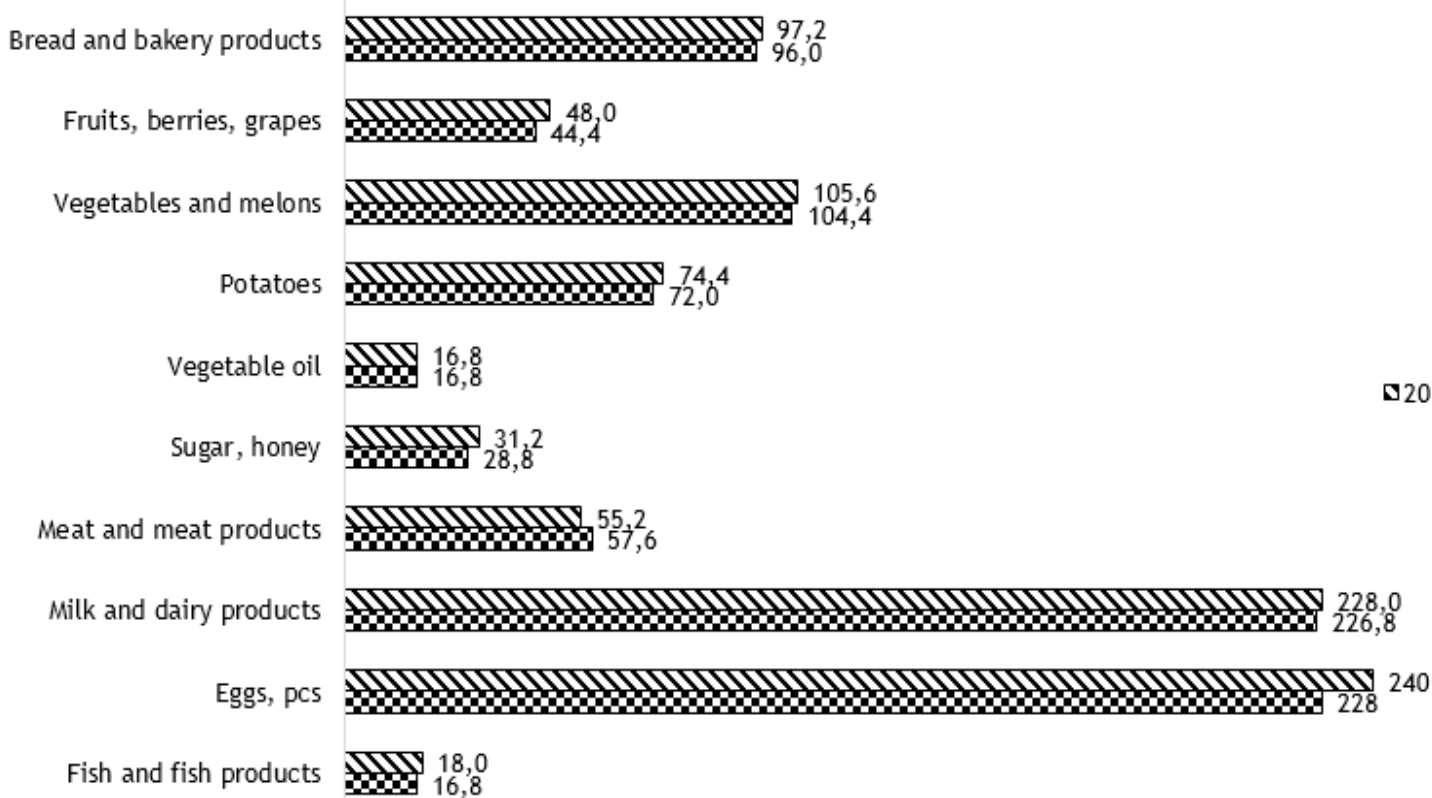

Figure 1. Consumption of food products in households (average on person per year), $\mathrm{kg}$

Source: Formed by author based on [5].

However, specialized organizations that study agricultural markets, having statistics for 2020, which was affected by the pandemic, make forecasts for the future. The new joint report of FAO and OECD provides key indicators on the development of agricultural sector for 2021-2030. The basic data are volumes of production the most important types of agri-food products, which, according to expectations, should grow steadily in the tenyear perspective, but for cereals and oilseeds along with products of their processing marketing years are taken as a basis, and for primary and processed livestock products - calendar years. In particular, the average annual wheat harvest in the world in 2018-2020 was 753 million tons, in 2025 it will be 802 million tons, and in 2030 - 840 million tons. Global rice production is projected to increase from the existing 509 million tons to 567 million tons in 2030, and various vegetable oils - from 213 million tons to 247 million tons, 
respectively [12, 14]. As for livestock, as of the end of the outlook year, forecasts that all types of meat will reach a total of 374 million tons compared to the existing volume of 330 million tons, and the global supply of milk on the planet will increase from 851 million tons to over a billion tons in 2030 ( Figure 2).

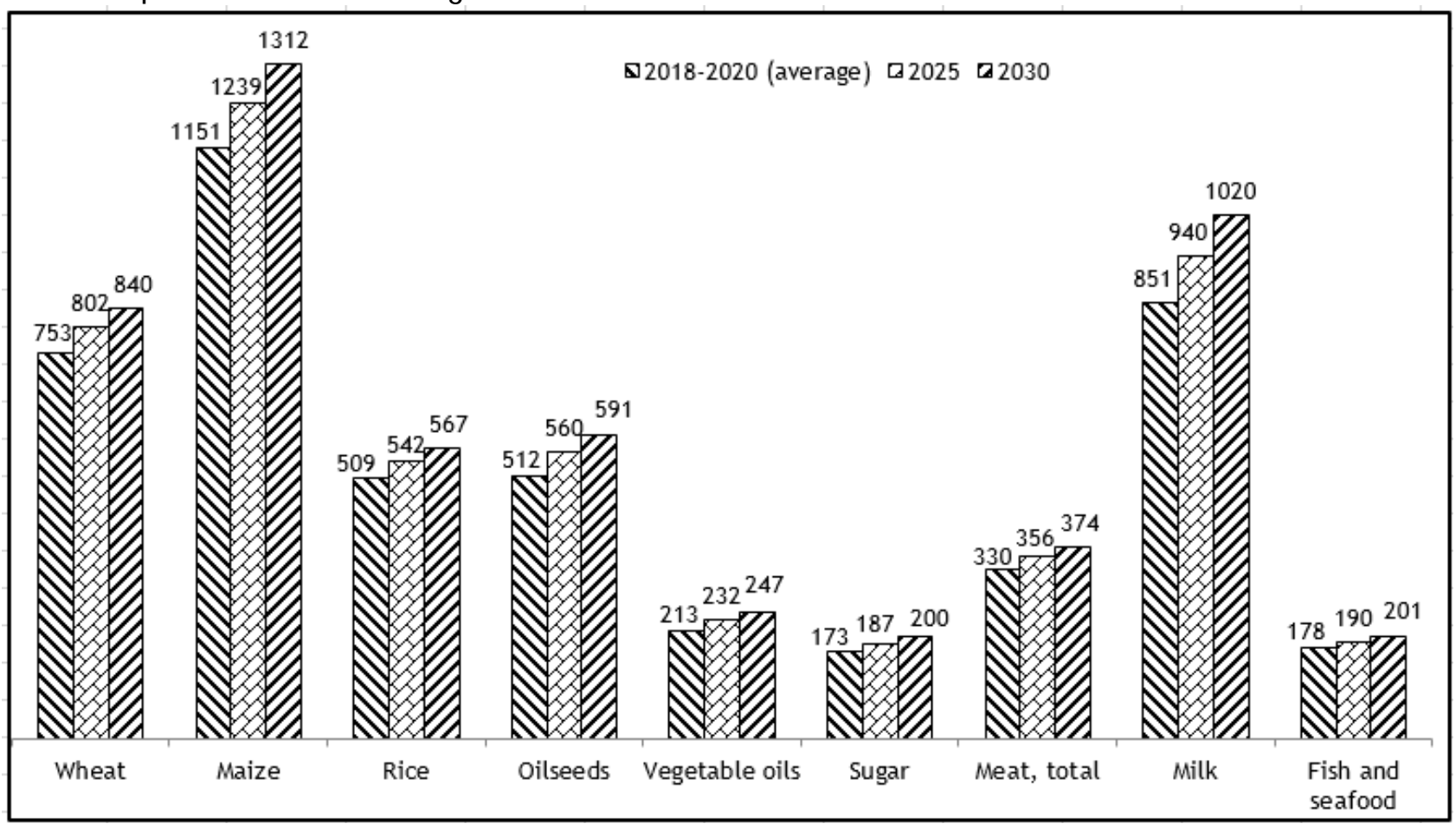

Figure 2. Forecast of agri-food production in the world, million tons

Source: Formed by author based on [14].

Also, OECD together with FAO in forecasts have identified several countries in each region, which are crucial in terms of the formation internal and external food security. This list also includes Ukraine (Table 2). According to the long-term estimates of these two organizations, our country will increase the production of wheat, maize, oilseeds and vegetable oil. The forecast for sugar produc- tion due to the unfortunate year for the domestic industry in 2020 was revised downwards. Overall meat production should increase, as pork and poultry will cover the slight drop in beef. In addition, current supply of milk will continue to decline, and the production of aquatic bioresources should stabilize and even show some growth [1, 12, 14].

Table 2. Forecast of agricultural production in Ukraine (thousand tons)

\begin{tabular}{|l|c|c|}
\hline \multicolumn{1}{|c|}{ Products } & 2018-2020 (average) & 2030 (forecast) \\
\hline Wheat & 26011 & 35858 \\
\hline Maize & 33988 & 44009 \\
\hline Oilseeds & 22040 & 26290 \\
\hline Vegetable oi & 6876 & 8403 \\
\hline Sugar & 1383 & 1236 \\
\hline Meat & 2234 & 2696 \\
\hline incl. beef & 365 & 325 \\
\hline Pork & 708 & 818 \\
\hline Poultry meat & 1146 & 1537 \\
\hline Milk & 9816 & 8926 \\
\hline Fish and seafood & 99 & 101 \\
\hline
\end{tabular}

Source: Formed by author based on [12, 14].

Taking into account an analyzed data, there is a clear impact of the coronavirus pandemic on both global food security and in relation to individual countries and regions. In the rather

short-term period of 2020-2021, it has led to overall unusually large rising in the number of people suffering from hunger and malnutrition, so final data have not yet been definitively 
established. There has also been an increase in absolute and relative food expenditures in both high-income and middle- and low-income countries. The toughest measures to control the disease by lockdowns and related restrictions on international trade were applied in early 2020, but the negative results of reformatting certain principles of the world economy really manifested itself only later in the form of rising world prices for essential goods (of first necessity), including food. At the same time, agri-food sector was one of the few to suffer the least from current pandemic $[3,8,9,17]$. In particular, production and international trade in key agricultural and food groups are projected will continue to grow, meeting the world's food needs.

Conclusions. Ukraine, being highly integrated into the world economic system, could not be left without feeling the effects of COVID-19 pandemic. Nevertheless, domestic agrarian business, though not immediately, managed to adapt to the changed economic conditions, by the end of 2020 setting one more regular record of exports and continuing this trend this year. On the other hand, contrary to the previ-

\section{Список бібліографічних посилань}

1. Аграрні перспективи України 2017-2030: Базовий сценарій. URL : https: //apd-ukraine.de/images/APD_APR_062017_AGMEMOD_Baseline_ukr.pdf.

2. Витрати і ресурси домогосподарств України у 2020 роцi. URL : http:// www.ukrstat.gov.ua/druk/ publicat/kat_u/ 2021/ zb/ 06/vrd_20_ue.pdf.

3. Власов В. І. Глобалістика: історія, теорія : монографія; у 2 т. Вінниця : ТОВ «Нілан-ЛТД», 2012. Т. 2. 856 с.

4. Державна митна служба України. URL : https:// customs. gov.ua.

5. Державна служба статистики України. URL : http:// www.ukrstat. gov.ua.

6. Експрес-огляд основних індикаторів продовольчої безпеки в Україні у 2020 році. URL : http://edclub.com.ua/ analityka/ ekspres-oglyad-osnovnyh-indykatoriv-prodovolchoyibezpeky-v-ukrayini-u-2020-roci.

7. Методичні рекомендації щодо оцінки ємності внутрішнього ринку сільськогосподарської продукції та продовольства / [Шпичак О. М., Лупенко Ю. О., Жук В. М. та ін.] ; за ред. О. М. Шпичака. Київ : ННЦ «ІAE», 2015. 56 с.

8. Формування глобального і регіонального ринків сільськогосподарської сировини та продовольства : монографія / [Ю. О. Лупенко, М. І. Пугачов, Б. В. Духницький та ін.] ; за ред. Ю. О. Лупенка, М. І. Пугачова. Київ : ННЦ «ІАЕ», 2015. 320 с.

9. Шпикуляк О. Г., Ходаківська О. В., Пугачов М. І., Грищенко О. Ю. Розвиток аграрного сектору економіки України в умовах впливу пандемії COVID-19. Економіка АПК. 2021. № 6. C. 26-41.

10. Data on expenditures on food and alcoholic beverages in selected countries. URL : https:// www.ers. usda.gov/topics/ international-markets-us-trade/ international-consumer-andfood-industry-trends.

11. FAO Food Price Index. URL : https://www.fao.org/ worldfoodsituation/ foodpricesindex/ en.

12. FAOSTAT. URL : http:// www. fao.org/faostat/ en.

13. International Trade Centre. URL http:// www. intracen. org. ous facts, there was an increase in agricultural imports to our country, and the main reason was not a pandemic, but ongoing systemic crisis in some sectors, which worsened, leading, among other things, to a serious increase in foreign supplies, for example, sugar and dairy products, mainly cheese. We can conclude that the share of imported products in the domestic food market for the first time in a long period exceeded $20 \%$ In 2020, Ukrainians reduced the quantitative consumption of most types of food, and in this year an additional unfavorable factor was a serious increase in their prices. As time has shown, even unprecedented safety measures and lasting vaccination in all regions of the world yet cannot stop the spread of coronavirus disease, social restrictions are not completely removed, creating a variety of complications. Current estimates and forecasts agree that the cost and prices of food will increase for both producers and consumers. Therefore, it is likely that in the near future food security and supplying in the world will take into account situation with the pandemic, and agricultural sector will constantly adapt to work with a high degree of uncertainty.

\section{References}

1. Agrarni perspektyvy Ukrainy 2017-2030: Bazovyi stsenariy [Agrarian prospects of Ukraine 2017-2030: Baseline scenario]. (2017). Retrieved from: https://apd-ukraine.de/ images/ APD_APR_06-2017_AGMEMOD_Baseline_ukr.pdf [In Ukrainian].

2. Vytraty i resursy domogospodarstv Ukrainy u 2020 rotsi (2021). [Expenditures and resources of households in Ukraine in 2020]. Retrieved from: http:// www.ukrstat.gov.ua/ druk/ publicat/ kat_u/ 2021/ zb/ 07/ zb_vrdu2020_pdf. pdf [In Ukrainian].

3. Vlasov, V.I. (2012). Globalistyka: istoriya, teoriya: monografiia u 2 t. [Globalistics: History, Theory: monograph: 2 vols. ]. Vinnytsya: TOV «Nilan-LTD» [In Ukrainian].

4. Derzhavna mytna sluzhba Ukrainy [State Customs Service of Ukraine]. Retrieved from: https:// customs. gov. ua [In Ukrainian].

5. Derzhavna sluzhba statystyky Ukrainy [State Statistics Service of Ukraine]. Retrieved from: http:// www.ukrstat.gov.ua [In Ukrainian].

6. Ekspres-ogliad osnovnykh indykatoriv prodovolchoi bezpeky v Ukraini u 2019 rotsi (2020). [Express review the main indicators of food security in Ukraine in 2019]. Retrieved from: http:/ / edclub.com. ua/ analityka/ ekspres-oglyad-osnovnyhindykatoriv-prodovolchoyi-bezpeky-v-ukrayini-u-2019-roci [In Ukrainian].

7. Shpychak, O.M., Lupenko, Yu.O., Zhuk, V.M., et al. (2015). Metodychni rekomendatsii shchodo otsinky yemnosti vnutrishnoho rynku silskohospodarskoi produktsii ta prodovolstva [Methodical recommendations for estimation the capacity of internal agricultural and food market]. O.M. Shpychak (Ed.). Kyiv: NNTs «IAE» [In Ukrainian].

8. Lupenko, Yu. O., Pugachov, M.I., Dukhnytskyi, B.V., et al. (2015). Formuvannia globalnoho i regionalnogo rynkiv silskogospodarskoi syrovyny ta prodovolstva: monografiia [Formation of global and regional markets for agricultural raw and food: monograph]. Yu.O. Lupenko, M.I. Pugachov (Ed.). Kyiv: NNTs «IAE» [In Ukrainian] 
14. OECD-FAO Agricultural Outlook 2021-2030. URL : https:/ / www. fao. org/ 3/ cb5332en/ cb5332en. pdf .

15. The State of Food Security and Nutrition in the World 2021. URL : https:// www. fao. org/ 3/ cb4474en/ cb4474en. pdf .

16. Overview of adopted COVID-19 trade measures. URL : https:// www. macmap. org/ covid19.

17. Christophe Béné, Deborah Bakker, Mónica JulianaChavarro, Brice Even, Jenny Melo, Anne Sonneveld. Global assessment of the impacts of COVID-19 on food security. Global Food Security, Volume 31, December 2021. URL https: / / www. sciencedirect. com/ science/ article/ pii/ S22119124 21000833?via\%3ihub
9. Shpykuliak, O.G., Khodakivska, O.V., Pugachov, M.I. \& Hryschenko, O.Yu. (2021). Rozvytok agrarnogo sektoru ekonomiky Ukrainy $v$ umovah vplyvu pandemii COVID-19 [Development an agricultural sector of Ukrainian economy in conditions of impact the COVID-19 pandemic]. Ekonomika APK, 6, pp. 26-41 [In Ukrainian].

10. Data on expenditures on food and alcoholic beverages in selected countries (2020). Retrieved from: https:/ / www. ers. usda. gov/ topics/ international-markets-ustrade/ international-consumer-and-food-industry-trends [In English]

11. FAO Food Price Index (2021). Retrieved from: https:// www.fao.org/ worldfoodsituation/ foodpricesindex/ en [In English].

12. FAOSTAT (2021). Retrieved from: http:// www.fao.org/ faostat/ en [In English].

13. International Trade Centre. (2021). Retrieved from: http:/ / www.intracen. org [In English].

14. OECD-FAO Agricultural Outlook 2021-2030 (2021). Retrieved from: https:// www.fao.org/3/ cb5332en/ cb5332en. pdf [In English].

15. The State of Food Security and Nutrition in the World 2021. (2021). Retrieved from: https:// www.fao.org/3/ cb4474en/ cb4474en. pdf [In English].

16. Overview of adopted COVID-19 trade measures (2021). Retrieved from: https:// www. macmap. org/ covid19 [In English].

17. Christophe Béné, Deborah Bakker, Mónica JulianaChavarro, Brice Even, J enny Melo \& Anne Sonneveld. Global assessment of the impacts of COVID-19 on food security. (2021). Global Food Security, Volume 31, December 2021. Retrieved from: https:// www. sciencedirect.com/ science/ article/ pii/ S2211912421000833?via\%3Dihub

\section{Духницький Б. В. Продовольче забезпечення в Україні та світі в умовах пандемї COVID-19}

Mета статmі - дослідити вплив пандемії COVID-19 на функціонування глобального ринку сільськогосподарської продукції, ситуацію з продовольчим забезпеченням в Україні та інших країнах, а також оцінити розвиток пов'язаних процесів в оглядовій перспективі.

Методика дослідження. Використано методи: теоретичного узагальнення - для опису ситуації, що склалася на світовому, регіональному та національних ринках агропродовольчої продукції внаслідок впливу пандемії коронавірусу з 2020 року nо теперішній час, аналізу і синтезу - для дослідження продовольчого забезпечення в масштабах окремих країн $і$ глобально нині та в найближчій перспективі з урахуванням актуальної на теперішній час ситуації, визначення підсумкових значень світової аграрної торгівлі у вартісному виразі за аналізований період, порівняльної оцінки - для зіставлення кількісних, вартісних та відносних показників, що характеризують продовольче забезпечення у 2019 та 2020 р., знаходження підтверджуючих чи заперечуючих відповідних трендів протягом неповного 2021 року, графічний і табличний - для кращої візуалізації кількісних показників, використаних у статті.

Результати дослідження. Розглянуто вжиття антипандемічних заходів у світі та Україні, показано зростання абсолютних і відносних витрат на продовольство в різних регіонах планети, наведено кількісні дані щодо голодуючого населення в окремих частинах світу, охарактеризовано ситуацію з імпортом агропродовольчої продукції в Україну та посиленням його впливу у 2020-2021 рр. на вітчизняний ринок, проаналізовано цінові індекси на продовольство у світі за даними ФАО та Україні згідно з інформацією державної статистики, в тому числі обсяги споживання, зведено прогнозні оцінки виробництва основних груп рослинницької і тваринницької продукції до 2030 року включно.

Елементи наукової новизни. Визначено різницю в показниках агропродовольчої торгівлі, витрат на продукти харчування, чисельності населення, що потерпає від голоду, а також індексів чін на основні продовольчі товари у світі та Україні зокрема між «допандемічним» 2019 роком та 2020-2021 рр., які характеризуються значним поширенням пандемії.

Практична значущість. Положення статті спрямовані на доведення інформації до українських аграрних підприємств зовнішньоекономічного профілю, споживачів продукції та державних органів стосовно змін на внутрішньому $і$ зовнішньому аграрних ринках з метою вироблення спільної стратегії і тактики можливих дій та системних заходів для запобігання негативних наслідків, пов'язаних із суттєвим збільшенням форс-мажорних обставин за останній період. Табл.: 2 . Рис.: 2. Бібліогр.: 17.

Ключові слова: пандемія COVID-19; обмеження торгівлі; продовольчі витрати; кількість голодуючих; індекс цін; споживання продуктів; прогноз виробництва.

Духницький Богдан Володимирович - доктор економічних наук, старший науковий співробітник відділу економіки аграрного виробництва та міжнародної інтеграції, Національний науковий центр «Інститут аграрної економіки» $(03127$, м. Київ, вул. Героїв Оборони, 10)

E-mail: duhnitsky@faust.kiev.ua

ORCID iD https:/ / orcid.org/ 0000-0002-5521-5602

\section{Духницкий Б. В. Продовольственное обеспечение в Украчне и мире в условиях пандемии COVID-19}

Цель статьи - исследовать влияние пандемии COVID-19 на функционирование глобального рынка сельскохозяйственной продукции, ситуацию с продовольственным обеспечением в Украине и других странах, а также оценить развитие связанных процессов в ближайшей перспективе.

Методика исследования. Использованы методы: теоретического обобщения - для описания ситуации, сложивщейся на мировом, региональном и национальных рынках агропродовольственной продукции вследствие влияния пандемии коронавируса с 2020 года по настоящее время, анализа и синтеза - для исследования продовольственного обеспечения в мас- 
штабах отдельных стран и глобально ныне, а также в ближайшей перспективе с учетом актуальной на сегодняшний день ситуации, определения итоговых значений мировой аграрной торговли в стоимостном выражении за анализируемый период, сравнительной оценки - для сопоставления количественных, стоимостных и относительных показателей, характеризующих продовольственное обеспечение в 2019 и 2020 г2., выявления подтверждающих или опровергающих соответствующих трендов в течение неполного 2021 года, графический и табличный - для лучшей визуализации количественных показателей, использованных в статье.

Результаты исследования. Рассмотрено применение антипандемических мер в мире и Украине, показан рост абсолютных и относительных расходов на продовольствие в разных регионах планеты, приведены количественные данные по голодающему населению в отдельных регионах планеты, охарактеризована ситуация с импортом агропродовольственной продукции в Украину и усилением его влияния в 2020-2021 г2. на отечественный рынок, проанализированы ценовые индексы на продовольствие в мире по данным ФАО и Украине в соответствии с информацией государственной статистики, в том числе объемы потребления, сведены прогнозные оценки производства основных групп растениеводческой и животноводческой продукции до 2030 года включительно.

Элементы научной новизны. Определены различия в показателях агропродовольственной торговли, расходов на продукты питания, численность населения, страдающего от голода, а также индексов цен на основные продовольственные товары в мире и Украине в частности между «допандемическим» 2019 годом и 2020-2021 г2., характеризующимися значительным распространением пандемии.

Практическая значимость. Положения статьи направлены на доведение информации украинским аграрным предприятиям внешнеэкономического профиля, потребителям продукции и государственным органам относительно изменений на внутреннем и внешнем аграрных рынках с целью выработки общей стратегии и тактики возможных действий и системных мер по предотвращению негативных последствий, связанных с существенным увеличением форс-мажорных обстоятельств за последний период. Табл.: 2. Илл.: 2. Библиогр.: 17.

Ключевые слова: пандемия COVID-19; ограничение торговли; продовольственные расходы; количество голодающих; индекс цен; потребление продуктов; прогноз производства.

Духницкий Богдан Владимирович - доктор экономических наук, старший научный сотрудник отдела экономики аграрного производства и международной интеграции, Национальный научный центр «Институт аграрной экономики» (03127, г. Киев, ул. Героев Обороны, 10)

e-mail: duhnitsky@faust.kiev.ua

ORCID iD https:/ / orcid.org/ 0000-0002-5521-5602

Стаття надійшла до редакції 29.07.2021 р.

Фахове рецензування: 16.08.2021 р.

Бібліографічний опис для цитування:

Dukhnytskyi В. V. Food supplying in Ukraine and the world under COVID-19 pandemic. Економіка АПК. 2021. № 8. C. 111 - 120. https:// doi. org/ 10.32317/2221-1055.202108111

Dukhnytskyi, B.V. (2021). Food supplying in Ukraine and the world under COVID-19 pandemic. Ekonomika APK, 8, pp. 111 - 120 [In English]. https:// doi.org/ 10.32317/ 2221-1055. 202108111 